\title{
Budget cuts mean no new projects for Indian science
}

New Delhl. The Indian government appears to have ignored pleas from leading scientists for a large increase in science funding by allocating less to research and development (R\&D) next year than needed to keep up with the anticipated rate of inflation. Most of the government's scientific agencies will, for the third year in succession, only have enough money to pay the salaries and housekeeping bills needed to keep existing research projects going, and will be unable to finance any major new projects.

According to figures announced last week, the total allocation for civilian R\&D in the 1994-95 budget will be $\$ 1,160$ million. This is an increase of only 3.6 per cent (\$43 million) over this year's figure, and compares to expected inflation of 8.5 per cent. Military research will do slightly better; it has been earmarked to receive $\$ 246$ million, up 7.5 per cent.

Apart from approving two new research vessels for the Department of Ocean Development, the government has not sanctioned a major new project in science and technology in any of its 400-odd research institutions. At the same time, however, the government is attempting to minimize the impact of 'subcritical' state funding for R\&D by setting up two new schemes for mobilizing resources from the private sector.

Under the first of these, companies who import technology from abroad are required to contribute a sum equivalent to five per cent on their royalty payments into the newly launched fund for technology development and application. This will be used to help the stage of commercialization".

Government officials hope that the new fund will generate between $\$ 25$ and $\$ 30$ million in 1994--95, and that the amount will grow considerably in future years with the significant increase in royalty payments by Indian companies to foreign organizations, which is expected to follow the new "indigenously developed technologies reach

\section{GATT agreements.}

Under the second scheme, the government has offered to give a tax credit of 125 per cent on all private contributions to publicly funded laboratories or universities.

The government's new budget keeps R\&D support for most industrial sectors at the same level -- or slightly higher -- as the current year. The exception is a marginal reduction in support for the electronics industry; given this cut, the Department of Electronics is to focus its research efforts on promoting projects in photonics and "massively parallel processing machines".

The biggest impact of the funding restrictions is likely to be felt by the Nuclear Power Corporation (NPC), whose plans have already been cut back, and which needs \$380 million during 1994-95 for its new atomic power plants.

The government is planning to provide the NPC with US\$60 million in next year's budget, and has asked the corporation to raise the rest of the money on the open market. But last year NPC only managed to raise $\$ 45$ million through the sale of bonds and equity shares, and the prospects for this year are even bleaker.

In contrast, the Department of Space (DOS) will see its budget grow from $\$ 240$ million to $\$ 252$ million. This confirms the government's resolve to proceed with the development of the geostationary launch vehicle (GSLV) programme on its own, following Russia's refusal to transfer the cryogenic rocket technology.

But if space researchers are satisfied, medical researchers are less so. One concern is that the priority given to the control of AIDS is leading to a resurgence of other communicable diseases. The new budget earmarks US\$27 million for the control of AIDS, more for all other communicable diseases combined; the outlay on malaria control, for example, is only $\$ 2$ million.

K. S. Jayaraman

\section{Pope to appoint bio-ethics committee}

Munich. The Vatican has announced that the Pope is to set up a new 'Pontifical Academy for Life' to advise him on biomedical ethics. The move is part of the Catholic church's contribution to the United Nations' Year of the Family.

The president of the academy will be Jérôme Lejeune, a fervent anti-abortionist who is a research director in France's National Centre for Scientific Research (CNRS) and also chairs the department of fundamental genetics at the NeckerEnfants Malades hospital in Paris.

Lejeune will be assisted by one ecclesi- astical and five lay counsellors. The academy itself will have 70 scientists as members, to be nominated by the Pope. According to the Vatican, academy Catholics, but they must be prepared to acknowledge that "life begins at the moment of conception".

The members of the academy will also be required to take an oath confirming their support for "the right to life", and their respect for "the catholic principle which condemns contraception, abortion and euthanasia". members will not necessarily have to be

\section{ANC seeks limits on nuclear power in South Africa}

Cape Town. The African National Congress (ANC), widely expected to emerge as the largest political party in South Africa's first all-race Parliament following April's elections, has confirmed its commitment to the Nuclear Non-Proliferation Treaty (NPT). It has also stated its belief that South Africa will not need any more nuclear power stations. There is one nuclear plant already in operation.

Speaking at a conference on nuclear policy held in Cape Town last month, Trevor Manuel, the head of the ANC's department of economic planning, said that the party's position on the NPT was consistent with its long-standing support for the Organization of African Unity's declaration to keep Africa free of nuclear weapons.

The highly enriched uranium from South Africa's seven dismantled nuclear weapons will, however, remain in the country, despite reported opposition from the United States. It seems likely that the ANC will continue to allow the uranium to be used by the Atomic Energy Corporation (AEC) to load its SAFARI reactor. This produces commercial radioisotopes, and also irradiates silicon for the manufacture of power-rectifiers.

If elected to power, the ANC has promised an immediate review of the state's subsidy to the AEC, currently due to rise to R509 (US\$100) million in the next financial year. The corporation has already promised to close its uranium enrichment plant by March 1996. But the manager of the plant, Piet Venter, says this could be done "within month" if necessary. The AEC's R\&D programme, in particular its molecular laser enrichment process, will also come under review.

The ANC has said that it will consider continuing support for a fuel fabrication plant to convert uranium oxide (yellowcake) to uranium hexafluoride, provided this can be carried out on a viable scale. The future of the corporation's fuel fabrication plant is closely linked to that of the country's nuclear energy industry, which will be considered by a proposed Energy Policy Council set up to formulate an integrated national energy plan for the country.

But a statement issued by ANC says that, given the current overcapacity in electricity generation in the country and the substantial potential for increasing imports of hydropower from southern Africa, it is clear that South Africa has "no need for further nuclear power stations". It has also promised to review the future of the country's only existing nuclear power station, situated at Koeberg, 28 kilometres north of Cape Town. Michael Cherry 